Original Research Paper

\title{
Financing Higher Education and Education Loans in India: Trends and Troubles
}

\author{
P. Geetha Rani \\ Professor and Head, Department of Economics, Central University of Tamil Nadu, Thiruvarur, India
}

\author{
Article history \\ Received: 11-04-2015 \\ Revised: 22-08-2015 \\ Accepted: 02-12-2016 \\ Email: geethselva@gmail.com
}

\begin{abstract}
The paper attempts to investigate the trends in financing higher education which convey that student loans is the dominating source of financing higher education in India. This leads us to explore various factors that influence, viz., enrolment growth, growing private sector, bulging youth population with growing middle class with a wider acceptability of loan culture and increasing earning premium of higher education and the willingness to pay. Using various secondary data sources besides using the unique data set made available on Interest Subsidy Scheme on Student Loans, we examine various troubles, namely who gets access to student loans and interest subsidy, what are the risks associated in terms of default or recovery and how the employability is linked with better repayments. We conclude that fees, grants/scholarships and student loans need to be examined in the context of increasing cost and role of markets in higher education along with affordability within the domain of family characteristics.
\end{abstract}

Keywords: Education Loan, Financing Higher Education, Income Quintiles, Caste Groups

\section{Introduction}

Student loans is one of the alternative sources of financing higher education for the credit constrained students. Capital market failure occurs because students are unable to obtain loans by pledging future earnings as collateral. Student loans by scheduled commercial banks in India is an attempt to ease out the capital market imperfections. But for the lender and borrower, credit markets for higher education involves uncertainty at different stages-viz., becoming a successful student, becoming a graduate, an employee and also the one who repays loans regularly, which is relied on his future earnings (Barr and Crawford, 2005; Chapman, 2006). If left to the market, there will be efficiency loss (as the talented but credit constrained students from poor family backgrounds would be unable to access higher education) and would result in distributional inequalities. Hence, the role of government in higher education financing is justified. Also one of the main objectives of education policy in India is providing equality of educational opportunities and also student loan program in India.
However, financing higher education is a highly contentious issue (Woodhall, 2007). Arguments in favour of public financing of higher education in India frequently cite social justice, fairness, equity and equality of opportunity (Tilak, 2004; Chattopadhyay, 2007). This equity argument often comes forth in defence of any attempts to raise fees in government funded educational institutions and/or introduction of student loans. But, handling the affordability and equity objective by subsidising everybody-as is the case when the same fee is uniformly charged-and without targeting actually ends up in promoting inequity (D'souza, 2004). It is argued further that participation in higher education in India is a minuscule proportion and is confined to the privileged sections. Hence, the claim that higher education makes the growth socially inclusive is debatable (Shah, 2008). Indeed, the children from well-off families exit publicly provided low quality school education to capture the freely provided or highly subsidised high cost and high quality public higher education (Geetha Rani, 2014). Equity is not achievable through blunt instruments such as subsidised education for all students as Tilak argues. 
Targeting is always more effective in promoting public objectives of equity (D'souza, 2004).

Yet another argument for private contribution to higher education finances is that tax funding of higher education redistributes towards the better-off. As argued by Barr and Crawford (2005) in the context of UK, letting them (students in higher education) not to pay for the lion's share of higher education is like subsidising champagne. On the same lines, Chapman (2006) argues that university education financed without direct contributions from the private beneficiaries is in essence regressive and inequitable. In the context of US higher education, it was argued that it is eminently desirable that every young man and woman, regardless of his or her parents' income, social position, residence or race, have the opportunity to get higher education-provided that he or she is willing to pay for it either currently or out of the higher income, the schooling will enable him or her to earn. There is a strong case for providing loan funds sufficient to assure opportunity for all... There is no case for subsidizing persons who get higher education at the expense of those who do not (Friedman, 1955 as quoted in Woodhall, 2007).

Such arguments have led to wider acceptance and introduction of student loans across developing and developed world. India is no exception to this global trend. The paper attempts to explore the prominent factors responsible for the growth in student loans during the recent decades in India. This work is an initial effort to understand the size, growth, distribution and various troubles of student loans in India. The rest of the paper is planned as follows. Section II sets the specific context to the paper highlighting the high growth trends in student loans. Section III presents the data sources and methodology. Section IV makes an analysis of probable factors for the growth of student loans. Section V explores the troubles in loan financing. Last section concludes with policy implications and raises further research questions.

\section{Growth of Student Loans: Trends}

Education loan scheme in India launched in 2001, is administered by scheduled commercial banks (for details see annexure 1) (It covers a wide range of courses in higher studies from post-matric to research, in India and abroad. Any student who secures admission in domestic/foreign educational institution is eligible to apply. There is no income ceiling on students/parents for the eligibility of this loan scheme. Loan amount covers both instructional cost and living expenses. Interest rate varies by loan slabs. It can be repaid in five to seven years and repayment would commence one year after completion of the course or six months after getting employment, whichever is earlier. Interest is charged during the period of study and till the completion of repayment). Since its inception, number of educational loans from 0.11 million, in 2000-01 increased to 2.59 million in 201314 (Table 1). The proportion of students enrolled in higher education who opted for education loans (All students who applied for education loans are not sanctioned with loans. However, rate of approval of education loan is above $95 \%$ as per the discussions with various bankers) constitute about $1.3 \%$ improved to around $8 \%$ during the same period.

Table 1. Growth of Education Loans in India

\begin{tabular}{lcccc}
\hline & $\begin{array}{l}\text { Education } \\
\text { Loans (in 000s) }\end{array}$ & $\begin{array}{l}\text { \% of Students Enrolled } \\
\text { in Higher and Tech Ed. }\end{array}$ & $\begin{array}{l}\text { Education Loans Released } \\
\text { (Rs. 10 millions) }\end{array}$ & $\begin{array}{l}\text { Ed. Loan as a \% of Govt } \\
\text { Exp. on Higher and Tech. Ed. }\end{array}$ \\
\hline $2000-01$ & 112.0 & 1.3 & 1028.0 & 5.1 \\
$2001-02$ & 157.0 & 1.8 & 1527.0 & 16.0 \\
$2002-03$ & 239.0 & 2.5 & 2870.0 & 28.2 \\
$2003-04$ & 347.0 & 3.5 & 4179.0 & 35.1 \\
$2004-05$ & 470.0 & 4.0 & 6398.0 & 50.6 \\
$2005-06$ & 641.0 & 4.5 & 10804.0 & 73.6 \\
$2006-07$ & 1002.0 & 6.4 & 14012.0 & 84.5 \\
$2007-08$ & 1215.0 & 7.1 & 19748.0 & 86.4 \\
$2008-09$ & 1580.0 & 8.5 & 26913.0 & 104.0 \\
$2009-10$ & 1911.0 & 9.2 & 35855.0 & 111.8 \\
$2010-11$ & 2211.0 & 8.0 & 41341.0 & 96.9 \\
$2011-12$ & 2373.0 & 8.3 & 46727.0 & 94.1 \\
$2012-13$ & 2479.0 & 8.4 & 50927.0 & 86.7 \\
$2013-14$ & 2590.0 & 7.8 & 70282.0 & 106.7 \\
GR $^{*}$ & 28.7 & 12.1 & 37.9 & 14.9 \\
\hline
\end{tabular}

Note: *Growth Rate, estimated by fitting a trend line $\mathrm{Y}=\mathrm{a}+\mathrm{bt}$ : Source: Statistical Tables relating to Statistics in India, Selected educational Statistics for the period 2000-01 to 2005-06; Selected Statistics on Higher and Technical Education since 2006-07 
Average annual growth rate of loan accounts was $28.7 \%$, while growth in enrolment in higher education was around $12 \%$. Also amount of education loans released increased rapidly from Rs. 10,280 millions (Rs. stands for Indian Rupees; $\$=$ INR.63.56) in 2000-01 to Rs. 702,820 millions in 2013-14. Increase was phenomenal at an annual average growth rate of $38 \%$, while rate of growth of government expenditure was at $15 \%$. Share of education loans constituted around $8.8 \%$ in total expenditure on higher and technical education in $2000-01$, increased to $85 \%$ by $2006-07$. Since $2007-08$, education loans exceeded government expenditures on higher and technical education.

It was pointed out that this shift of costs from parents and taxpayers to students had taken place 'seemingly without public awareness and thus perhaps with neither rationale nor intent' while analyzing the cost sharing in USA, U.K., France, Germany and Sweden (Johnstone, 1986). In the Indian context, despite the arguments such as imperfections of market and discrimination practised by banks and education loans cannot be a solution for students willing to pursue higher education (Chattopadhyay, 2007), education loans both in number and finances are contributing to the growth and financing of higher education in a big way. This indicate a clear shift of burden from taxpayers and parents to students. Trend growth rates indicate that education loans would be further increasing at a similar rate or even more. It is because government financing towards higher education is though increasing but not in pace with demand for higher education in India (detail in later section). Further, a statistical analysis of data on Gross Domestic Product (GDP) by the Reserve Bank of India (RBI) suggests that a $1 \%$ increase in GDP growth is associated with 5\% increase in education loan (Dr. K.C. Chakrabarty, Deputy Governor, Reserve Bank of India at the Panel Discussion on GenNext Banking at the 4th International Finance and Banking Conference organized by the Indian Merchant's Chamber on November 25, 2009 in Mumbai). However, it can plummet if global recession persists. As risk averse students may not be willing to borrow given their employment prospects in the labour market.

\section{Data and Methodology}

The paper uses secondary data sources such as Statistical Tables Relating to Banks in India, published by
Reserve Bank of India; Selected Educational Statistics, Selected Statistics on Higher and Technical Education and Analysis of Budgeted Expenditure on Education published by Ministry of Human Resource Development; Economic Surveys of India published by Ministry of Finance. Unpublished secondary data comes from Indian Bank Association (IBA) and Canara Bank. The paper uses possibly a unique data set made available by the nodal bank which operates the Central Sector Interest Subsidy Scheme (CSIS) on education loans (Eligibility criterion for students to get this interest subsidy is parental income with less than Rs. 450 thousands). It covers all students who received interest subsidy under the Ministry of Human Resource Development (MHRD) scheme (www.mhrd.nic.in) during the period 2009-10 to 2012-13 (Table 2).

Data corresponds to those students who claimed interest subsidy, constitute around 30 to $40 \%$ of the students who took education loans. Each observation corresponds to a loan profile, viz., loan limit, interest rate and year of sanction. Parental income is available and are self reported incomes ratified from a designated Government official for availing interest subsidy. However, there is no way of verifying this claim. Characteristics of individual and household borrower include gender, caste viz., General, Other Backward Caste (OBC), Scheduled Caste (SC) and Scheduled Tribe (ST), religion (Christian, Muslim, Sikh, Other Minority, Not Minority), disability and location (Metro, Urban, Semiurban and Rural). It does not cover all students who took loans hence suffer from selection bias. Despite the limitation, it captures few select household, social and economic characteristics of student loan borrowers.

\section{Methodology}

We divide the borrowers into five quintiles using parental income and compare few key determinants' summary statistics such as mean size of education loan and interest subsidy (details in annexure 2) depicted in Charts 2-4 and Table 6 and A2. In doing this, we try to understand the relationship between loan size and interest subsidy across socio-economic groups. We also attempt to understand the discrimination or disadvantage in the access to education loans across gender and caste groups in a highly stratified society like India. We estimate gender gap, income gap and income-caste gap to discern the extent of discrimination among various groups of student population.

Table 2. Interest subsidy accounts and amount sanctioned

\begin{tabular}{|c|c|c|c|c|}
\hline Period & $\begin{array}{l}\text { Interest subsidy } \\
\text { Accounts* }\end{array}$ & $\begin{array}{l}\text { Education loan } \\
\text { Accounts }\end{array}$ & $\begin{array}{l}\% \text { of interest subsidy beneficiaries } \\
\text { in Education Loan availed }\end{array}$ & $\begin{array}{l}\text { Interest Subsidy (Rs } \\
\text { in } 10 \text { Millions) }\end{array}$ \\
\hline $2009-10$ & 618860 & 1928350 & 33.41 & 296.86 \\
\hline 2010-11 & 838655 & 2235532 & 40.18 & 735.49 \\
\hline $2011-12$ & 698316 & 2287843 & 42.99 & 1198.88 \\
\hline $2012-13$ & 854728 & 2509465 & 34.06 & 1295.47 \\
\hline
\end{tabular}

Source: Based on data from Canara Bank; Banking Statistics Relating to Banks India, Reserve Bank of India, relevant reports 
Further to understand the relationship between government expenditure on higher education and student loans, we attempt to estimate the elasticity coefficients by estimating the following regression:

$\ln Y_{i}=\alpha+\beta \ln X_{i}$

where, $Y$ is government expenditure on higher and technical education and $X_{1}$ is advances on student loans. In a double log-linear model, the slope coefficient $\beta$ measures elasticity of $Y$ with respect to $X$, i.e., percentage change in $Y$ for a given percentage change in $X$. Using the double log linear model, we estimated the elasticity between the number of students enrolled in higher and technical education and number of student loan accounts and the elasticity between per student government expenditure on higher and technical education and per student loans advanced. These are estimated using all India data and pooled panel data across states (All states are included. All north eastern states and all union territories are included as one observation each given their small size.) for 2000-01 to 2013-14, results reported in Table 5.

Besides, the paper being a position paper develops many analytical tables using various secondary data sources. Rapid growth in student loans is fraught with troubles viz., defining who is meritorious but poor students; who gets access to student loans; what is the relationship between the size of loans and structure of interest rates; what is the nature of the relationship between government expenditures on higher education and student loans; how employability is linked with better repayments and what are the risks associated with student loans in terms of default or recovery rates. The present paper adds value to understand the recent trends and troubles in financing higher education in India. It also estimates the extent of willingness to pay for higher education by estimating the elasticity coefficients between government and bank finances for higher education. It evaluates who benefits from student loans after it is being in operation for more than a decade. In doing so, it makes an attempt to estimate the cost of higher education across social and economic groups besides estimating the cost of higher education by courses. To a larger extent, cost of higher education, a major determinant of student loans is unobservable in this data set, however implicit in amount of loans. So, education loan captures that part of cost of higher education (Hence, it can be assumed that education loan represent the cost of higher education, though indicative.) which the family resources could not afford.

\section{What are the Driving Forces behind Financing of Higher Education through Bank Loans?}

Enrolment growth or widely referred as massification of higher education, growing private sector, the bulging youth population with growing middle class with a wider acceptability of loan culture and increasing earning premium of higher education and the willingness to pay for higher education are the prominent factors which influence a rapid growth in education loans. This section attempts to position these factors in the Indian context with an empirical analysis.

\section{Massification of Higher Education}

Globally, there has been rapid expansion and demand for higher education known as massification of higher education, including India. Enrolments in higher education increased on an average $12 \%$ per annum (column 6 of Table 3 ). However, only $20 \%$ by $2011-12$ in the age group of 18-24 enrol, very less compared to China or even Asia's average. Yet another dimension implicit in Table 3 (columns 2 and 5) is the structure of gross enrolment ratio by levels of school and higher education which canvass the extent of inequality of access to different levels of education in India. It can be implicitly inferred that a huge proportion of children are filtered away at school education.

Table 3. Enrolment Ratio and Enrolment in Higher Secondary and Higher Education in India

\begin{tabular}{llllll}
\hline & $\begin{array}{l}\text { GER-secondary } \\
(14-18)(2)\end{array}$ & $\begin{array}{l}\text { Dropout rates } \\
(\mathrm{I}-\mathrm{X})(3)\end{array}$ & $\begin{array}{l}\text { Board results in } \\
\text { Hr. Sec (in \%) (4) }\end{array}$ & $\begin{array}{l}\text { GER- Hr. } \\
\text { Education (5) }\end{array}$ & $\begin{array}{l}\text { Enrolment in Hr. } \\
\text { Edn (in 000s) (6) }\end{array}$ \\
\hline $2001-02$ & 33.26 & 68.6 & 59.6 & 8.07 & 8821.1 \\
$2002-03$ & 37.52 & 66.0 & NA & 8.97 & 9516.8 \\
$2003-04$ & 38.89 & 62.6 & NA & 9.21 & 10009.1 \\
$2004-05$ & 39.91 & 62.7 & 71.0 & 9.97 & 11777.3 \\
$2005-06$ & 40.42 & 61.9 & 71.7 & 11.55 & 14323.6 \\
$2006-07^{*}$ & 41.13 & 61.6 & 69.6 & 12.39 & 15552.5 \\
$2007-08^{*}$ & 45.81 & 56.7 & 72.3 & 13.10 & 13591.8 \\
$2008-09$ & 47.40 & 54.2 & 72.9 & 13.70 & 15212.5 \\
$2009-10$ & 49.40 & 52.7 & 78.5 & 15.00 & 17295.1 \\
$2010-11$ & 52.20 & 49.2 & 79.1 & 20.40 & 27499.7 \\
$2011-12$ & 56.80 & 50.3 & NA & 30.00 & 28562.7 \\
$2016-17^{\wedge}$ & 75.00 & NA & NA & $11.9 \&$ \\
\hline
\end{tabular}

Note: NA- Not Available; Source: *Statistics on School Education; Selected Educational Statistics; ^ GER targets in the 12th Five Year Plan; and Growth rates; Results of Higher Secondary School Examination, various issues 
The cumulative dropout rates up to Class $\mathrm{X}$ indicate that almost $50 \%$ of enrolled children in class I drop out by the time they transit to class $\mathrm{X}$. High rates of dropout rate at secondary level mean low transition rates and low gross enrolment ratios in higher education (To successfully participate in the current knowledge revolution it is essential to have significant proportion of the workforce trained to at least high school level). Adding to this, the poor face a highly imperfect credit market, in which to borrow against expected higher future earnings to finance their investments in education, an important channel for getting out of poverty is denied to millions of people. Nonetheless, the point to be noted is even with this $50 \%$ turnout lead to substantial demand for higher education. Further, results in senior secondary examination indicate that around $80 \%$ of children appeared in examination pass out and hence eligible to enter into higher education (column 4 of Table 3). Places in higher education institutions would be inadequate for this growing demand. This excess demand has led to the growth of private unaided higher educational institutions in India.

\section{Expanding Private Sector}

Educational institutions in India are categorised into three groups based on funding: (i) Government institutions set up and funded by the state; (ii) privateaided institutions under private management but receive as much as $97 \%$ of their expenses from the state exchequer; and (iii) privately managed and wholly selffinanced institutions which do not directly receive any funding from government. Until the middle of 1980s, government and private-aided institutions dominated the field. The latter were set up and managed by religious, charitable and philanthropic organisations termed as fused private-public entities. Wholly self-financing private institutions cater both to elites and non-elites. The latter category has become increasingly important from the $1990 \mathrm{~s}$ especially in professional education, because government and government-aided institutions have been unable to meet the rapidly growing demand for higher education.

Though higher education in the eleventh and twelfth five-year plans in the new millennium is boosted, private sector has been contributing to the growth of higher education in a big way. In other words, growing social demand for higher education is often met by private higher educational institutions, wherein cost of higher education is higher. That share of institutions by private unaided sector is almost $60 \%$. Yet enrolment shares of government and government funded institutions is around $60 \%$ of total enrolment (Table 4).

Yet another dimension implicit in the structure of management type is towards creating inequality in educational opportunity. That participation of students in these three types of management of institutions is determined by its access, availability and affordability. Since private unaided sector is expanding predominantly among professional courses, cost of higher education is on the increase. Preference for sanctioning loans for students enrolled in professional courses implicitly facilitate the growth of private unaided sector. Private sector is expected to accentuate especially when India's young population is bulging.

\section{Younger and Aspiring Population of India}

India has the opportunity to reap the 'demographic dividend' (an increase in the ratio of the population aged 15-64 years to that aged 0-15 years and above 65 years) till 2040, after which the population would start ageing (Talreja, 2014). This benefit can be materialised only if this huge potential of the working age population is channelized in the right direction, that is, if the labour force can be gainfully skilled and employed. Younger India has tremendous potential to export manpower through skill migration particularly when developed countries are facing declining birth rates and increasing life expectancy. Further, the Indian population is projected to grow at a rate of $1.6 \%$ per annum while GDP is expected to grow at a rate of $8-9 \%$ per annum. As a result, the per capita income is expected to quadruple by 2020 . The Indian middle class is expected to expand by more than 10 times from its current size of 50 million to 583 million people in next 18 years (Dr. K.C. Chakrabarty, Deputy Governor, Reserve Bank of India at the Panel Discussion on GenNext Banking at the 4th International Finance and Banking Conference organized by the Indian Merchant's Chamber on November 25, 2009 in Mumbai).

In this demographic scenario, the college-going population is increasingly diverse, that emerging demand for higher education predominantly come from the growing middle class in India (Mukherjee and Satija, 2012). This younger generation is far more open to consumer loans, student loans, etc. Favourable demographic edge along with income trends in terms of salaries, savings and expenditure are expected to act as catalysts in boosting higher education. Consumer spending patterns in pursuing education reflects people's willingness to invest in education. It is because education is increasingly perceived as a safe and longterm investment as manifested in their preference over student loans vis-a-vis other personal loans. Disbursement of student loans has risen from 3\% in 2009 to almost double in 2013 of total personal loan portfolio. The student loan portfolio grew by around $20 \%$ during 2009 to 2013 (Table 5). 
Table 4. Distribution of Institutions and Enrolment by Government and Private Sector in India

\begin{tabular}{|c|c|c|c|c|}
\hline Type & $2000-01 *$ & $2005-06 *$ & 2010-11 & 2012-13 \\
\hline \multicolumn{5}{|l|}{ Institutions } \\
\hline Government & 33.2 & 25.0 & 26.8 & 26.9 \\
\hline Private Aided & 42.1 & 32.0 & 14.2 & 14.9 \\
\hline Private Unaided & 24.7 & 43.0 & 59.0 & 58.2 \\
\hline Total & 13072 & 17973 & 16499 & 24120 \\
\hline \multicolumn{5}{|l|}{ Enrolment } \\
\hline Government & 41.0 & 35.8 & 39.2 & 37.7 \\
\hline Private Aided & 37.3 & 33.5 & 23.8 & 22.7 \\
\hline Private Unaided & 21.7 & 30.7 & 37.0 & 39.6 \\
\hline Total (in $000 \mathrm{~s}$ ) & 8399 & 10481 & 11552 & 16853 \\
\hline
\end{tabular}

Source: * Agarwal (2009); All India Higher Education Survey.

Table 5. Comparison of Student Loans with Other Components of Personal Loans

\begin{tabular}{lllllll}
\hline Components & 2009 & 2010 & 2011 & 2012 & 2013 & GR \\
\hline No. of Accounts (Relative Proportion to Personal Loans) & & & & & \\
Housing & 11.22 & 14.84 & 11.41 & 11.86 & 13.82 & 3.59 \\
Consumer Durables & 3.04 & 2.24 & 2.49 & 2.29 & 2.03 & -6.07 \\
Vehicles & 12.83 & 10.50 & 10.64 & 9.49 & 9.32 & -5.64 \\
Education & 2.99 & 5.01 & 4.49 & 4.84 & 5.63 & 14.93 \\
Personal Credit Cards & 37.07 & 23.36 & 35.04 & 34.14 & 33.45 & 3.39 \\
Others & 32.86 & 44.06 & 35.93 & 37.38 & 35.75 & 1.65 \\
Personal loans (in 000 s) & 50,914 & 40,687 & 52,419 & 54,708 & 47,545 & 1.60 \\
Credit Limit (Rs. in Millions) & & & & & \\
Housing & 33879.7 & 37662.3 & 43251.5 & 47843.4 & 58319.3 & 14.17 \\
Consumer Durables & 1045.8 & 768.6 & 939.7 & 1007.2 & 1165.2 & 4.98 \\
Vehicles & 9796.9 & 7007.4 & 10137.1 & 10652.7 & 11777.3 & 8.19 \\
Education & 3377.7 & 4981.7 & 6099.1 & 6741.2 & 6898.7 & 18.89 \\
Personal Credit Cards & 11091.1 & 10111.2 & 10837.2 & 12320.2 & 13799.4 & 6.55 \\
Others & 20191.9 & 20113.1 & 27921.4 & 30038.9 & 32158.3 & 14.25 \\
Personal loans & 79383.2 & 80644.3 & 99185.9 & 108603.5 & 124118.2 & 12.65 \\
\hline
\end{tabular}

Note: Figures are for the month of March ending of respective years; Source: Basic Statistical Returns of Scheduled Commercial Banks in India

Student loans perform remarkably well, while consumer durables and vehicles show negative growth rates reflecting the overall depression in the economy, impact of the global crisis. One of the major reasons for increasing demand for higher education is the increasing private returns or wage premium to higher education.

\section{Higher Private Returns to Higher Education}

Earnings premium for a college degree relative to a high school degree nearly doubled in the last three decades in many countries. Further, there is no particular evidence this earnings premium has declined as a result of the Great Recession. Rather the unemployment rate in USA for college graduates and above was $4.4 \%$, while high school graduates faced an unemployment rate of $8.5 \%$ and those with collegiate attainment less than a BA faced an unemployment rate of $7.6 \%$ in 2011 (Avery and Turner, 2012). The simplest measure of the earning premium or private returns is higher salaries graduates receive compared with non-graduates'. The recent estimates on private returns to education in India suggests that there is an incentive to acquire higher levels of education as returns to higher education are positive and monotonically increasing (Fig. 1).

High return to higher education is leading to rapid development of credit markets for higher education in some developing countries in the past decade (Calclough et al., 2009). India witnesses it in terms of growth in student loans. As argued earlier, this high private returns to higher education implicate for a higher contribution from students. But the rates of return to education varies across social groups. For instance, Geetha Rani (2013) estimated that returns to higher education vary ranging from $-29.10 \%$ among the SC/ST workers with the highest returns of $26.1 \%$ among Brahmin/high caste group.

\section{Nature of the Relationships-Complementary or} Substitute?

One of the major arguments of raising fees and hence to finance higher education via student loans is that households have the ability and willingness to pay for higher education, given the increasing private rates of return to higher education. But what is the nature of the relationship between student loans and government 
expenditure on higher education? In other words, how does the demand for student loans by the household respond to government expenditure on higher education? Households opting for student loans can complement government expenditures by positively responding to increase in government expenditures. Alternatively, they can substitute with government expenditure resulting with an inverse relationship between the two. At the extreme, they can indifferently react with neither an increase nor a decrease. Table 6 reports the estimated elasticity coefficients between government and bank finances of higher education.

Three important implication from the estimates on elasticity coefficients:

- Coefficients of elasticity in all three cases clearly show that government expenditures and Student Loans (either in monetary, numbers or per student) do not substitute each other, instead they complement each other. The elasticity coefficients are statistically significant in all the cases except per student category

- Value of the co-efficient in all three cases are less than one indicating it is less elastic. It means that an increase in government expenditure by Rs. 100 would mean a decline of Rs. 40 in Student Loans at the national level. However, the picture in pooled regression is different with a decline in Student Loans to the tune of Rs. 27 across states. But the differences get narrowed down when the elasticity coefficients is estimated in numbers at the national and across pooled state level observations

- In all three cases, we find that elasticity coefficient is greater than zero but less than one and indicate that higher education is a basic need

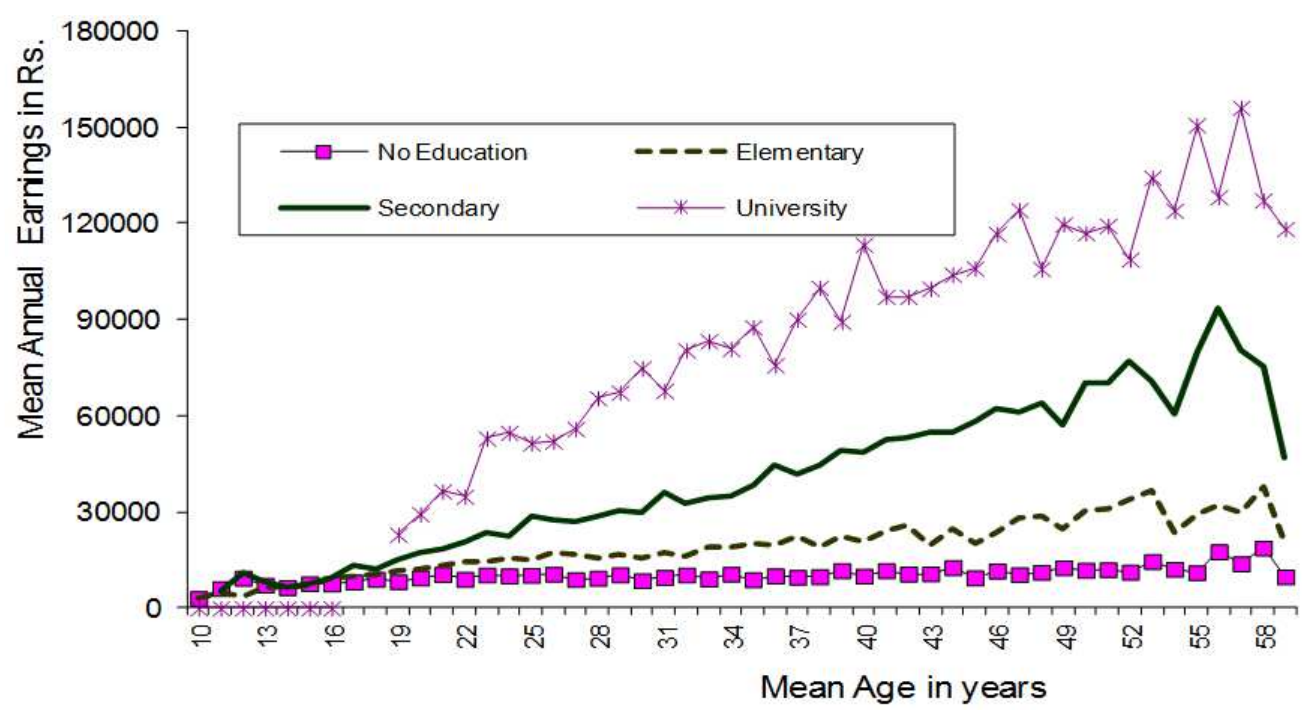

Fig. 1. Age-earnings profiles of persons between age group 10-60 by levels of education in India; Source: based on Unit Data, Indian Human Development Survey

Table 6. Results of regression and pooled regression

\begin{tabular}{|c|c|c|c|c|c|c|}
\hline & \multicolumn{2}{|c|}{ Govt Expr on Ed Loan } & \multicolumn{2}{|c|}{ Enrol on Loan Accounts } & \multicolumn{2}{|c|}{$\begin{array}{l}\text { Per Student Exp on } \\
\text { Per Student Loan }\end{array}$} \\
\hline & COEF & SE & COEF & SE & COEF & SE \\
\hline \multicolumn{7}{|l|}{ Regression } \\
\hline Slope & $0.402 * * *$ & 0.075 & $0.423 * * *$ & 0.035 & 0.321 & 0.245 \\
\hline Constant & $6.245 * * *$ & 0.718 & $6.871 * * *$ & 0.239 & $10.412 * *$ & 4.617 \\
\hline Number of observations & 14 & 14 & 14 & & & \\
\hline Adjt. R2 & 0.679 & 0.917 & 0.052 & & & \\
\hline \multicolumn{7}{|l|}{ Pooled Regression } \\
\hline Slope & $0.278 * * *$ & 0.024 & $0.457 * * *$ & 0.024 & 0.015 & 0.042 \\
\hline Constant & $4.772 * * *$ & 0.129 & $8.667 * * *$ & 0.233 & $9.099 * * *$ & 0.494 \\
\hline Number of observations & 282 & 253 & 242 & & & \\
\hline Adjt. R2 & 0.321 & 0.58 & -0.0036 & & & \\
\hline
\end{tabular}

Note: $* * * \mathrm{p}<0.01, * * \mathrm{p}<0.05$ 
It may be said that bank loans as one of the alternative sources of finance to higher education should be designed in such a way that the public spending/subsidy on higher education need not be crowded out by loan financing of higher education. It needs to work as supplement rather than as a substitute to government financing of higher education in the context of a country characterised by wide regional/social/gender disparities.

\section{Troubles}

Recognising the increasing share of market forces in higher education, recent committees constituted by Government of India (NKC, 2008; Yashpal, 2009) suggest that primary focus should, therefore be on making education affordable, either through scholarships or loans. In this discourse, fees, grants/scholarships and student loans need to be examined in the context of increasing cost and role of markets in higher education along with affordability within the domain of family characteristics. We examine here some of the troubles and problems in the approach towards the provision of student loans in the Indian context. In the light, the moot questions are: Is the access to student loans progressive or regressive? Does it affect the demand for higher education of weaker sections? Does it benefit the rural and urban; boys and girls; and caste groups equally? What is the relationship between course structure and loan size? What is the structure of interest rates and loan size? What is the nature of relationship between government and bank finances of higher education? What are the issues of recovery and default rates? What is the link between repayment and employment opportunities?

\section{Defining Meritorious but Poor Students and Affordability}

The objective of student loan program in India is that, 'meritorious student, though poor, is provided with an opportunity to pursue education with financial support from the banking system with affordable terms and conditions' (www.mhrd.nic) (The education loan scheme was formulated by Indian Bankers Association (IBA) in 2001 for adoption by all scheduled commercial banks (www.iba.org)). This statement raises a number of questions: Who are meritorious but poor students? What extent the meritorious but poor students get access to student loans? What are affordable terms and conditions? Mechanism through which these three important terms-meritorious, poor and affordable terms get translated as operating parameters of student loan assume significance.

The term meritorious appears to be indicated/defined in the eligibility criterion of student loans as all courses having employment prospects; Graduation/Post
Graduation/Professional and Other courses approved by University Grants Commission/Government /All India Council for Technical Education, etc. But the eligibility criterion does not spell about the marks obtained from last qualifying examination (details Table A1 in Annexure 1).

Defining poor in getting the access to student loans is ambivalent. An important yet implicit criteria adopted by banks in sanctioning any loan including student loans is based either on credibility of the borrowers or employability of the course. Households differ in their financial endowment and their children's ability. It is important to note that banks have discretion as to who they loan to and how much, because banks require"...collateral security... in the form of suitable third party guarantee".

'Affordability' means inexpensive and reasonably priced as per Oxford English dictionary. Affordability in the case of student loans needs to be a variant of borrower as families are differentially endowed. Hence, assessing affordability entail the cost of courses in higher education and the family income, rather ability of the family contribution to higher education. A perusal of student loan application forms of major public sector banks indicate almost all scheduled commercial banks attempt to get information on the cost estimates of the course in a comprehensive manner. The same is not true to get information on sources of parental income and parental liabilities to arrive at potential parental contribution. Hence, it can be argued that financial need is more or less a perceived need of the student's family.

Student loans are categorized based on loan limits of three slabs and the operating parameters such as interest rates, requirement of margin money (down payment) vary. For instance, loans below Rs. 400 thousands require no guarantor, security and margin money, while loans between Rs. 400 to Rs. 750 thousands require collateral security in the form of suitable third party guarantee. Five per cent of loan amount as margin money is required for loans above Rs. 400 thousands for studies in India and 15\% for Studies Abroad. Loans with a limit of above Rs. 750 thousands require tangible collateral security, margin money varying between 5 to $15 \%$, depending upon whether the student studies in India or abroad. Hence one can presume that many deserving poor students who cannot provide collateral might be denied above Rs. 400 thousands category loans. This appears to be the case given the distribution of loans by slabs that more than $80 \%$ of the loan accounts are unsecured loans category during the period 2009-10 to 2011-12 (Table 7). However, the situation has changed in $2012-13$ only $60 \%$ of the loan belong to this category. But loans advanced are only $60 \%$ in the unsecured category across the four years. Yet another noteworthy trend is that almost 25 to $30 \%$ of loan amounts go to above Rs. 750 thousands category. 
Table 7. Distribution of Student Loans by Slabs in India

\begin{tabular}{llllll}
\hline Item & Slabs (Rs. in thousands) & $2009-10$ & $2010-11$ & $2011-12$ & $2012-13$ \\
\hline Accounts & Unsecured Loans* & 84.82 & 86.78 & 87.66 & 60.44 \\
& Above Rs. 400 and up to Rs. 750 & 8.91 & 7.71 & 5.34 & 11.76 \\
& Above Rs. 750 & 6.27 & 5.51 & 7.00 & 27.80 \\
Amount & Total & 420908 & 542296 & 611517 & 13094 \\
& Unsecured Loans* & 58.3 & 61.53 & 60.44 & 58.12 \\
& Above Rs. 400 and up to Rs. 750 & 15.4 & 15.78 & 11.76 & 10.87 \\
Per Student Loan & Above Rs. 750 & 26.2 & 22.70 & 27.80 & 31.02 \\
& Total & 11900 & 15207 & 13094 & 12091 \\
& Unsecured Loans* & 194476 & 198817 & 147637 & 216313 \\
& Above Rs. 400 and up to Rs. 750 & 489766 & 573881 & 471210 & 497071 \\
& Above Rs. 750 & 1182109 & 1154587 & 850411 & 1284418 \\
& Total & 282727 & 280416 & 214118 & 317784 \\
\hline
\end{tabular}

Note: * Unsecured loans are the loans below Rs. 4,00,000; Source: IBA

It is quite possible that this loan amount goes to better off sections of the society given the credit worthy requirements. In terms of per student loans, unsecured loan category is around Rs. 200 thousands. On the other hand, per student loans of secured category is around Rs. 1100 thousands (Table 7). Banks tend to discriminate in favour of those clients who either provide collateral or who belong to a financially stable family. The design of the program itself induces education loans less accessible to low income households.

\section{Who gets Access to Student Loans and by how} much?

As elucidated, the better off, the ones in the richest income quintile would get the highest size of loans. Average size of student loans on the secondary y-axis in Fig. 2 remained similar over the years in each income quintiles. Income gap, depicted in bar graph remained same across time, for instance, average education loan in the poorest income quintile in 2012-13 was Rs. $2,02,391$, while in the richest income quintile, it was Rs. 3,00,93. It categorically favours relatively better off students who has the capacity to take higher loans. Further in the same chart, the gaps across the line graphs in the interest subsidy (see annexure 2) is measured in the y-axis. Distance between the line graphs indicating the income gap in each year remain almost same over 2009-10 to 2012-13. However, average interest subsidy increased over the period. The irony is that the interest subsidy which is means tested but based on the principle of equal subsidy for all favours the ones who has taken higher amounts of loans. The blanket equal subsidy, 'one size fits for all' approach promotes inequity in real sense.

Such discrimination prevail in the access to higher education as pointed out by Central Advisory Board of Education's (CABE, 2005). In the bottom/poorest quintile (monthly per capita consumption expenditure quintile), only $1 \%$ of the population has higher education and the ratio steadily climbs to above $10 \%$ in the richest quintile during 1999-2000. That population with higher education is directly proportionate to household economic status in rural as well as urban areas.

Access to higher education, student loans and the means-tested interest subsidy scheme not only favours the rich, but also male students (Chart 3). Gender discrimination is universal across income groups and also over the years. Gender gap is worked out as the difference in student loans (interest subsidy) between male and female student beneficiaries. Gender gap in education loan, depicted in bar graphs in secondary yaxis, depict an edge of female students over average size of student loans across income quintile Q2 during all years except 2010-11. Gender gap in interest subsidy, the line graph in $\mathrm{x}$-axis in Fig. 3, do not reveal any pattern either across income groups or over the years. Nonetheless, it can be noted that during all four years interest subsidy was favourable to male students. Gender discrimination is quite evident in the access to interest subsidy available in education loans and credit markets in higher education in India. Similar discrimination is quite prevalent in both labour market and pre-market situations in India.

Yet another related disadvantage for women is student loans being treated as negative dowry in the marriage market. Marriages in India are characterized by payments of dowries of huge amounts which broadly connotes a transfer of wealth made by the family of the bride to that of the groom at the time of 'arranged' marriages. Numerous instances can be cited where rising dowry levels have been associated with higher education and hence better employment of the grooms. Though dowry is a social evil, hierarchy of occupations, came to dictate dowry levels. Dowry is being practised even though there is a law on Dowry Prevention Act in 1961 itself. For example, uppermiddle-class doctors, engineers and Indian Administrative Service officers claimed the highest dowries, followed by lawyers, company executives 
and senior bureaucrats. In this socio cultural milieu, student loans operate differentially in the marriage market for men and women. Student loans obtained by men for accessing higher education and eventually for a better employment are expected to bring in higher dowry. On the contrary, for women who borrow and subsequently marry, whose loan commitments constitute a form of negative dowry. For instance in USA, Gicheva (2012) explores the relationship between student debt and the probability of marriage and finds that additional student debt of $\$ 10,000$ decreases the long-term probability of marriage by 7 percentage points.

\section{Discrimination by Caste and Income Groups}

Stratification based on caste in India is deep rooted and about 3000 years old. Labour markets in India have historically been organized along caste lines. An important feature of these caste networks is that they are typically the most active among the highly skilled or educated (or white collar) occupations, dominated by high caste. Education policy is supposed to break this cycle given its objective of access to equality of opportunity. On the contrary, such discrimination is apparent in terms of both student loans and interest subsidy across income groups over the years (Fig. 4A and Table A2 in Annexure 1).

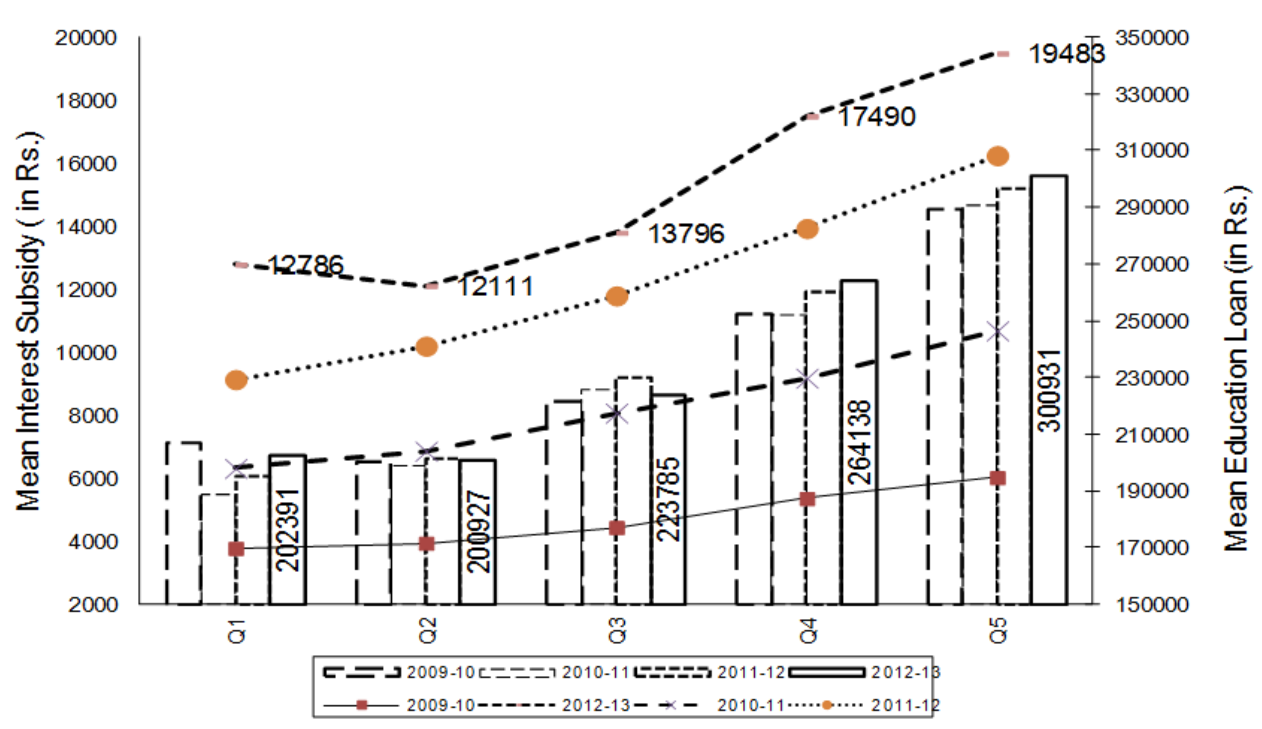

Fig. 2. Mean student loans and mean interest subsidy by income quintiles; Source: unit data

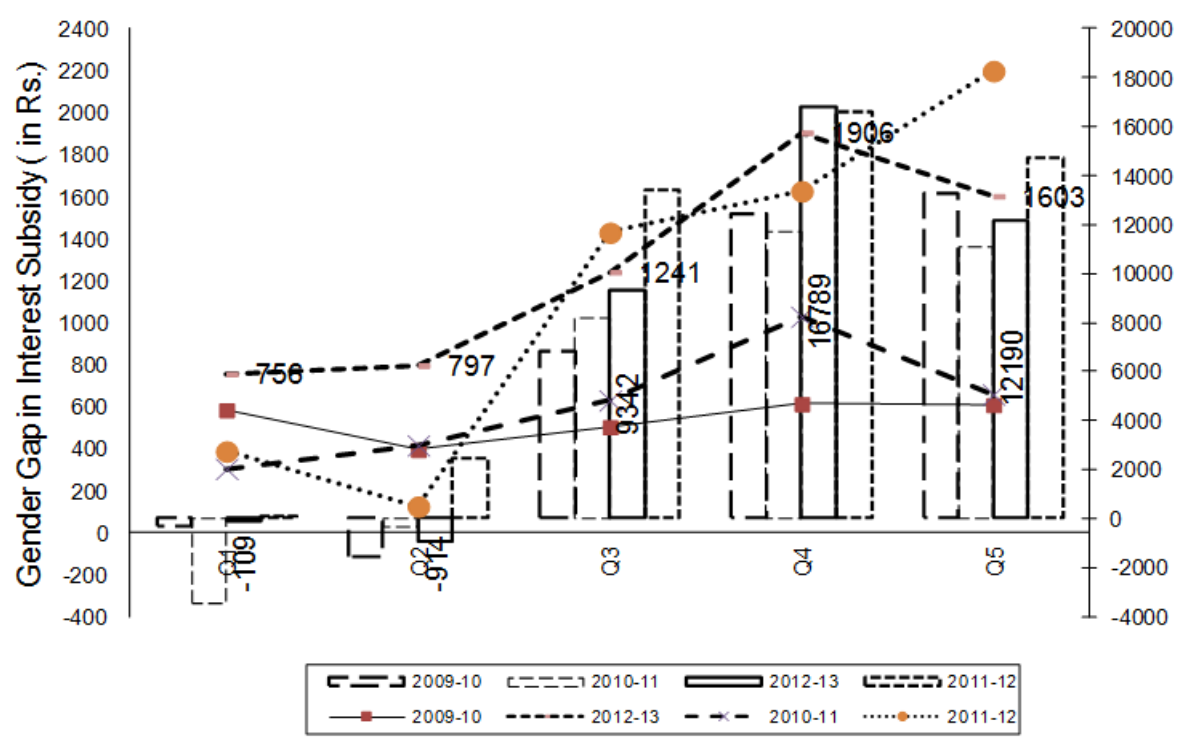

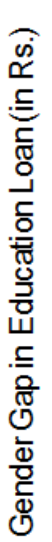

Fig. 3. Gender gap in student loans and interest subsidy by income quintiles; Source: Unit data 


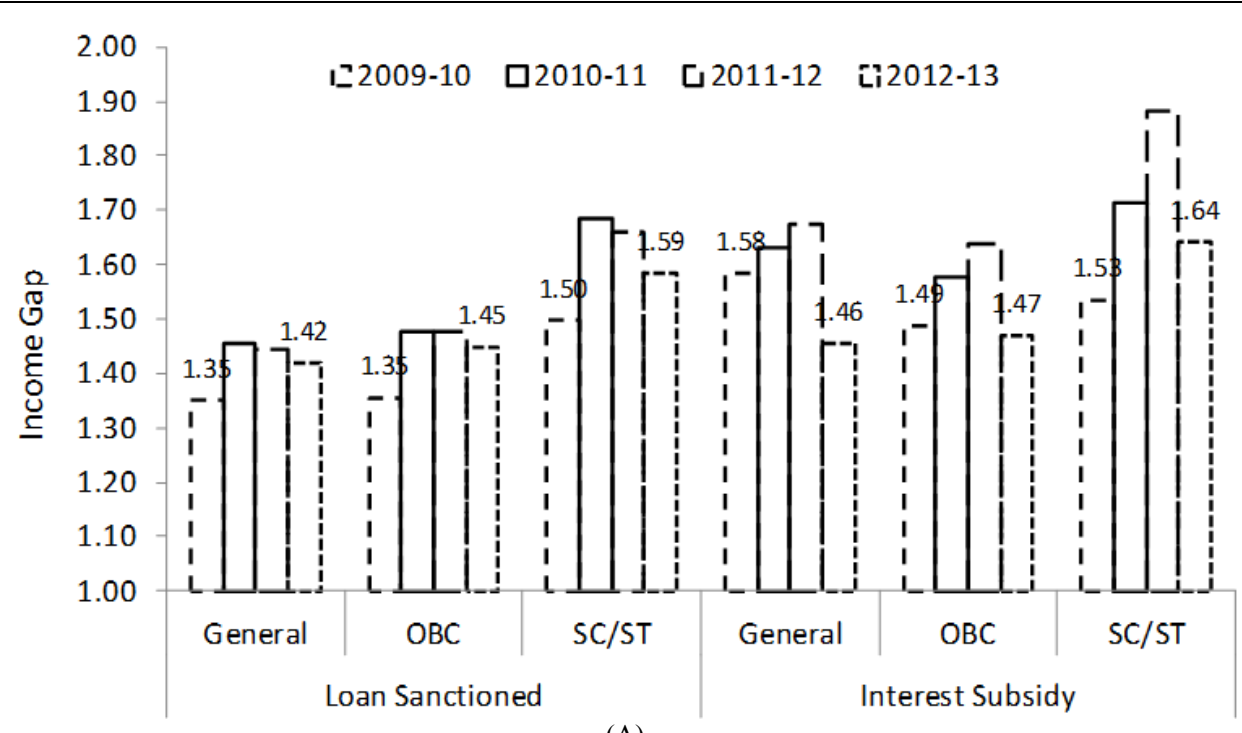

(A)

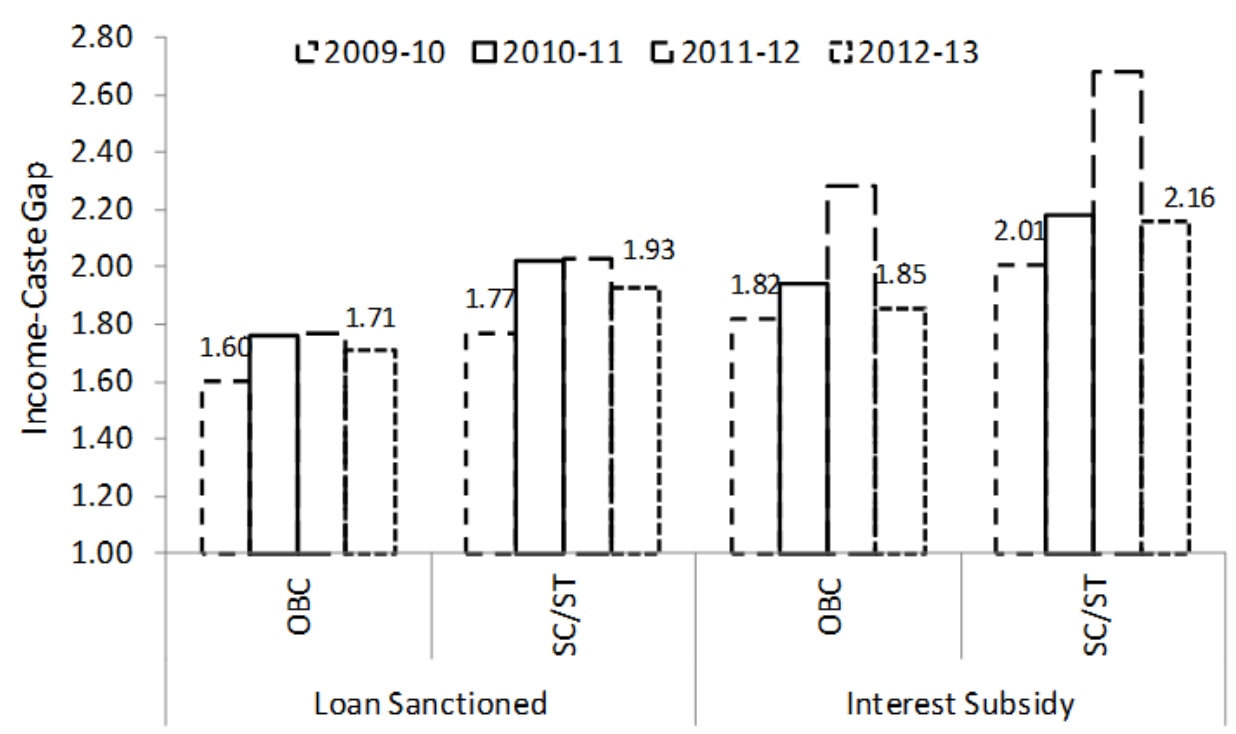

(B)

Fig. 4. (A) Income Gap in Loans Sanctioned and Interest Subsidy in India; Source: Based on Table A2 in Annexure 1 (B) IncomeCaste Gap in Loans Sanctioned and Interest Subsidy in India Source: Based on Table A2 in Annexure 1

Income gap is estimated as the ratio of mean education loan (or interest subsidy) of the richest income quintile to that of poorest income quintile. Income gap within each caste groups across mean education loans and interest subsidy over years depict an inverted $U$ shaped pattern. Income gap declined in the later year within each group. But between groups, income gap remained the lowest among general or high caste category. It is almost similar among OBC groups. On the other hand, it remained the highest among SC/ST, the most deprived caste groups in India. Income gap in average interest subsidy lingered higher than in education loan both within and between groups.
Income and caste hierarchy jointly is decisive to access the lowest interest subsidy by the poorest SC/ST groups of Rs. 3206 as against almost the double of Rs. 6445 among the richest general (high) caste groups in 2009-10 (Table A2 in Annexure 1). Income-Caste gap is estimated as the ratio of mean education loan (interest subsidy) of the richest income quintile of the General Caste (reference category) to that of the poorest income quintile of either OBC or $\mathrm{SC} / \mathrm{ST}$ groups. Income-caste gap like income-gap follow an inverted $U$ shaped pattern across loan and interest subsidy (Fig. 4B). Similar pattern emerge across within and between groups but the magnitude 
of gap is higher in income-caste gaps, double disadvantage of economic and social deprivation.

Socioeconomic privilege confers many direct benefits, both through a home culture which tends to reinforce the goals of formal education and through the capacity to fund access to education in private schools for a later capture of access to higher education in a review in European countries (Asplund et al., 2008). Similarly in India, children from richest income groups exit from publicly provided low quality school education to capture the freely provided or highly subsidised high cost and high quality public higher education (Geetha Rani, 2014). The underrepresentation of less affluent socioeconomic groups in higher education has important implications for social policy, economic efficiency and social justice.

\section{Course Structure and Size of Student Loans}

Besides social and economic groups, tuition charges and student loans across course structure does promote inequity an imbalance in the overall course requirements at the macro level. The structure of tuition charges is determined in part by subsidies and in part by course costs, with the latter differing markedly (Chapman, 2006). For instance, the cost/education loan for medicine are six times more than low-cost courses such as education. Given such structure of course costs (education loan), equal interest subsidies across courses essentially create unequal interest subsidy across courses. Interest subsidy for medicine, the high cost course gets the highest subsidy over the years. Gap (Gap is measured as the ratio of Loan Size (interest subsidy) of Medicine to that of Education.) between education loans across the high cost course Medicine and for instance one of the low cost courses, Education widens from 5.17 in $2009-10$ to 7.98 by $2011-12$ and marginally declined to 7.61 in 2012-13. Gap between the same courses across interest subsidy increased from 2.32 in $2009-10$ to 7.08 by 2012-13 (Table 8 ).

Preference of courses by students and family can indicate not only the choice and affordability but also expected future earnings. Course wise education loans and interest subsidy indicate that highest loan provided to is medical course, followed by architecture, law, fashion, management. Both medical and architecture get more than Rs. 3,00,000 on an average. While courses like Diploma, Commerce and Education obtained the least amounts less than Rs. 100 thousands. Also in that hierarchy those courses which acquired highest loans were served with highest interest subsidy. Furthermore, the relationship between the size of loan and the number of years of study may be pressurizing less advantaged students into opting for shorter duration and/or more vocational courses (Forsyth and Furlong, 2003).

Table 8. Student Loan and Interest Subsidy and by Disciplines in India (in Rs.)

\begin{tabular}{|c|c|c|c|c|c|c|c|c|}
\hline \multirow[b]{2}{*}{ Course name } & \multicolumn{2}{|l|}{$2009-10$} & \multicolumn{2}{|l|}{ 2010-11 } & \multicolumn{2}{|l|}{ 2011-12 } & \multicolumn{2}{|l|}{$2012-13$} \\
\hline & $\begin{array}{l}\text { Education } \\
\text { Loan }\end{array}$ & $\begin{array}{l}\text { Interest } \\
\text { Subsidy }\end{array}$ & $\begin{array}{l}\text { Education } \\
\text { Loan }\end{array}$ & $\begin{array}{c}\text { Interest } \\
\text { Subsidy }\end{array}$ & $\begin{array}{l}\text { Education } \\
\text { Loan }\end{array}$ & $\begin{array}{l}\text { Interest } \\
\text { Subsidy }\end{array}$ & $\begin{array}{l}\text { Education } \\
\text { Loan }\end{array}$ & $\begin{array}{l}\text { Interest } \\
\text { Subsidy }\end{array}$ \\
\hline Medical & 335077 & 5726 & 326511 & 10568 & 333370 & 17095 & 344461 & 21642 \\
\hline Architecture & 291815 & 4795 & 248745 & 5097 & 313408 & 9410 & 314137 & 11744 \\
\hline Law & 232654 & 4052 & 181779 & 5708 & 252480 & 11546 & 278437 & 15208 \\
\hline Fashion & 271637 & 4739 & 300749 & 14230 & 297536 & 14367 & 274430 & 15104 \\
\hline Management & 269925 & 7785 & 261922 & 13130 & 274918 & 18811 & 259212 & 19069 \\
\hline Nursing & 231394 & 3503 & 249507 & 7421 & 239743 & 10683 & 237839 & 10699 \\
\hline Engineering & 231024 & 4378 & 225797 & 7640 & 232726 & 11440 & 234054 & 14620 \\
\hline Pharmacy & 228000 & 4813 & 229268 & 7447 & 233133 & 10528 & 233495 & 12410 \\
\hline Hospitality & 225602 & 4770 & 230876 & 8662 & 226708 & 11642 & 231271 & 13827 \\
\hline Others & 194762 & 4198 & 190731 & 7359 & 193005 & 11167 & 205557 & 14357 \\
\hline Physiotherapy & 215592 & 3493 & 99630 & 3170 & 196133 & 6886 & 205438 & 8948 \\
\hline Science & 178799 & 3560 & 159277 & 5459 & 176742 & 7875 & 172293 & 9392 \\
\hline BCA/MCA* & 157131 & 3326 & 220669 & 7315 & 155837 & 6633 & 157227 & 8374 \\
\hline Diploma & 117078 & 2968 & 145851 & 5069 & 124348 & 6122 & 125821 & 8203 \\
\hline Commerce & 115713 & 2404 & 151124 & 5127 & 99255 & 4274 & 97502 & 5348 \\
\hline Education & 64860 & 2467 & 66123 & 2767 & 41776 & 2793 & 45265 & 3057 \\
\hline All & 233949 & 4708 & 229907 & 8188 & 235692 & 12261 & 238322 & 15162 \\
\hline CV (\%) & 29.24 & 27.46 & 29.42 & 37.84 & 32.64 & 34.50 & 32.17 & 31.19 \\
\hline Gap $^{\wedge}$ & 5.17 & 2.32 & 4.94 & 3.82 & 7.98 & 6.12 & 7.61 & 7.08 \\
\hline
\end{tabular}

Note: CV-Coefficient of Variation; *BCA-Bachelor of Computer Applications; MCA-Master of Computer Applications; ${ }^{\wedge}$ refer foot note 13; Source: Unit data 
Credit market in student loans cater to a narrow section of student community depending on their choice of courses, primarily professional and market oriented courses. In addition to these courses, the socioeconomic background play an important role in accessing student loans. Such a distribution tend to indicate that students from well off families and market oriented courses enjoy an edge over students who are not so well off and pursue non-market oriented courses. This potentially creates new inequalities whereby students from poorer backgrounds qualify to diploma level and those from more affluent backgrounds achieve professional degrees (Christie and Munro, 2003). Courses such as medical and engineering are not only relatively long duration and high cost courses but also high paying degrees. This pattern indeed perpetuate the inequality across life time earnings. Such competition in the market would result in imbalance in the course structure as more and more able and talented students opting for market oriented courses than the conventional courses, creating an imbalance. This may lead to shortage of teachers in pure and basic science, mathematics and humanities disciplines as being experienced in India.

\section{Structure of Interest Rates and Size of Student Loans}

Interest rates are one of the significant parameters in deciding the implicit subsidy or the hidden cost of student loans. Usher (2005) while reviewing the global debt burdens in OECD countries argue that there are three basic approaches to dealing with student loan interest rates: "zero-nominal", "zero-real" and "cost of government borrowing". In the zero-nominal interest approach, the loan does not grow in nominal terms for the duration of the study period. In real terms, the loan shrinks while the student is in school, has the largest government subsidy. No real interest is charged under zero-real interest approach, but loans are allowed to grow with inflation so as to remain in constant value. This too enjoys larger government subsidy but less than zero nominal type. In the category of cost of government borrowing there is no subsidy at all or as in Jhonstone's words no gift to the borrower.

Interest rate on education loans in India is fixed around the base rates which broadly cover the cost of banks' borrowing as set by Reserve Bank of India. Interest rate varies across public sector banks. This is not only by default but also by design of the program. For instance in one of the popular banks, popularly known as people's bank, loan is charged with floating interest rate of $12.25 \%$ per annum for loan amounts below Rs. 400 thousands or unsecured loans (w.e.f 27.06.2008). The next slab is charged with $13.75 \%$ for loan amounts between Rs. 400 and Rs. 750 thousands and the third slab is charged with $12.75 \%$ per annum for loans above Rs. 750 thousands. Though the interest rates marginally varied across select public sector banks, yet the pattern is followed (Table 9). The interest rates are not progressively charged with higher amounts of loans.

\section{Impact on Employability}

By and large, countries with higher endowments of skilled labour will benefit from the current technological scene. Evidence from earlier studies suggests human capital positively influences productivity, growth, employment and Foreign Direct Investment. In the Indian context, Maiti and Mitra (2010) argue that with higher levels of education the quality of labour and thereby their employability in the formal sector of the economy, would be enhanced. Repayment and recovery of education loan rely on the quality turnout of students who can be absorbed in the labour market with better earnings. The linkage elucidate the quality of final products that can be absorbed in the labour market at competitive prices. So, employment and earnings is directly related with either repayment or default. Borrowers who end up in low paid jobs, most probably would turn out to be unlucky borrowers. When they default, the challenge is tracing the students who moved out of their residences, educational institutions and also changing jobs.

Table 9. Mean Interest Rates Charged across Banks in India

\begin{tabular}{llll}
\hline Bank groups & Below Rs. 400000 & Rs. 400001 and Rs. 750000 & Above Rs. 750,000 \\
\hline State Bank and Associates & 11.74 & 12.29 & 11.7 \\
Allahabad Bank & 12.20 & 11.96 & 11.81 \\
Canara Bank & 10.75 & 11.41 & 10.46 \\
Central Bank of India & 10.88 & 10.89 & 10.67 \\
Corporation Bank & 11.63 & 12.06 & 11.61 \\
Oriental Bank of Commerce & 10.97 & 11.61 & 11.48 \\
Syndicate Bank & 10.96 & 10.98 & 10.74 \\
Union Bank of India & 11.80 & 12.15 & 11.91 \\
United Bank of India & 11.62 & 11.88 & 11.09 \\
Grammeen banks & 12.12 & 12.39 & 12.07 \\
\hline
\end{tabular}

Source: Unit Data 


\section{Recovery and Default Rates}

The financial efficacy of any loan program depends on the size of the recovery ratio--extent to which loans are repaid. Recovery rate on student loans depends crucially on four main factors: Whether repayments are linked to inflation; amount of interest subsidy on loans; repayment losses owing to non repayment (default); and administrative costs (Ziderman, 2002). Two key indicators, viz., repayment ratio and recovery ratio evaluate the financial efficiency and sustainability of a loan program respectively. Repayment ratio depends principally on interest rates charged to borrowers relative to the cost of capital. As discussed earlier, the loan program in India charges students an interest rate higher than the base rate (cost of capital) and hence expected to have a better repayment ratio. Additionally, duration of grace period, study period and repayment span all affect the relative present values of repayment and origination streams, which are stringent in the Indian loan program.

Overall recovery ratio matters and is based on rate of repayments and administrative costs. So, it depends on default rates, governance of student loan program and loan collection system in place. Financial efficiency or recovery ratio can be evaluated if information on individual profile of loanees over the loan cycle is available. With the limited information, we present here a glimpse of loans outstanding (Table 10).

Loan advances increased at an annual average growth rate of $38 \%$. Similarly, loans outstanding also increased at an annual average rate of $34 \%$. Outstanding loan as a proportion of Student Loans constitute around more than $60 \%$ of loans released. Though this may not be an ideal way of examining performance of loans, this crude indicator reports with huge percentage of loans outstanding against loans advanced. Comparing education loan with other components of personal loans such as housing, consumer durables, vehicles and personal credit cards, indicate that not only student loan advances growing faster as reported in Table 9 but also the growth rates of loans outstanding is also the highest with $21 \%$ during the period 2009 to 2013 (Table 11). On the contrary, Shen and Ziderman (2009) report 80\% repayment ratio of loan by State Bank of India, one of the highest ratios reported among many developed and developing nations. As an other side of a coin, they report default rates of $7 \%$, one of the lowest among many developed and developing nations.

Table 10. Student Loans Outstanding in India (Rs in 10 millions)

\begin{tabular}{llll}
\hline & Loan Advances & Loans Outstanding & \% Outstanding in Advances \\
\hline $2003-04$ & 4179 & 3053 & 73.06 \\
$2004-05$ & 6398 & 4393 & 68.66 \\
$2005-06$ & 10804 & 6695 & 61.97 \\
$2006-07$ & 14012 & 11219 & 80.07 \\
$2007-08$ & 19748 & 14391 & 72.87 \\
$2008-09$ & 26913 & 20258 & 75.27 \\
$2009-10$ & 35855 & 26925 & 75.09 \\
$2010-11$ & 41341 & 35292 & 85.37 \\
$2011-12$ & 46727 & 41344 & 88.48 \\
$2012-13$ & 50927 & 46700 & 91.70 \\
$2013-14$ & 70282 & 50954 & 72.50 \\
GR & 37.9 & 33.7 & -- \\
\hline
\end{tabular}

Source: Statistical Tables relating to Banks in India, RBI

Table 11. Comparison of amount outstanding across other components of personal loans*

\begin{tabular}{lllllll}
\hline Components & 2009 & 2010 & 2011 & 2012 & 2013 & GR \\
\hline Housing & 284751 & 306307 & 345931 & 378744 & 464711 & 12.66 \\
Consumer Durables & 7373 & 5759 & 6564 & 7347 & 8213 & 4.70 \\
Vehicles & 59824 & 44634 & 65717 & 70366 & 81619 & 11.37 \\
Education & 24848 & 38380 & 46990 & 52005 & 55044 & 20.86 \\
Personal Credit Cards & 30214 & 21807 & 20676 & 22179 & 25446 & -3.21 \\
Others & 146536 & 142008 & 184256 & 219509 & 236257 & 14.92 \\
Personal loans & 553546 & 558895 & 670135 & 750151 & 871291 & 12.77 \\
\hline
\end{tabular}

Note: *Rs in Millions; Source: Statistical Tables relating to Banks in India, RBI 
Even for this low default rates in comparison with many loan programs, banks are concerned that defaulters of student loan has been on the rise. To counter this, a proposal to set up the Credit Guarantee Fund is on the pipeline by Government of India. However, to avoid low repayment rates, banks tie up with reputed institutions and prefer to provide loans to students from those institutes. In other words, banks tend to discriminate against the more default-prone students-the poorer students and those enrolled in institutions of lower standing. From the perspective of a lender, asymmetric information and difficulty in collection of payments may be deterring. The problem of asymmetric information arises because lenders may know little about the ability of students seeking loans, their ambitions and intended career paths. This leads to the associated problem of adverse selection because it discriminates against students from economically challenged sections of society (Chattopadhyay, 2007).

Student loan leads to various problems such as discrimination based on credit worthiness while sanctioning loans, no priority given to students' merit, no progressive interest rate charges across loan size, equal rates of interest subsidy across loan size inherently leading to inequity, among many others. By and large, the better off benefit because of their credit worthiness in getting a higher loans but also served with relatively lesser interest rates. Also the students with higher amounts of loans enjoy the benefits of highest amounts of interest subsidy. Uniform interest subsidy do not benefit students equally across courses, caste, gender and income groups. In a similar vein, Usher (2004) argued that need-based assistance is found to be an inefficient way to help low-income students; more direct incometargeting methods should be adopted if policy-makers wish to use financial assistance programs to help lowincome students to access higher education.

\section{Conclusion and Policy Implications}

State policies on universal public financing of higher education have a pervasive effect on both allocation of resources in higher education and its inherent unequal distribution of benefits to the better off in the society. Student loans predominantly cater to the students enrolled in private sector and market oriented courses. As evidenced here, loan size and hence (means-tested) interest subsidy favours the rich male and high caste groups. Also highly market-oriented courses get the highest education loans and by default get the highest interest subsidy. This would further accentuate the inequality in the society. Both public and bank financing of higher education widens the gap between the haves and have nots to access higher education and credit markets in higher education respectively.
Hence, fees, grants or scholarships and student loans need to be examined in the context of increasing cost of higher education along with affordability within the domain of family characteristics in a highly stratified society of India. Moreover, it is not just access to and financing of higher education alone matters. Prior to higher education, the kind of quality schooling children attend is also equally important. Because of credit constraints, children and their families face both short and long term credit constraints (Carneiro and Heckman, 2002). The short term constraints can be addressed with measures like grants, interest subsidy, scholarships, subsidised loans, etc focusing on higher education. But the long term credit constraints are more important in the context of bulging youth population, the demographic dividend of India.

The Union budget proposal in 2014-15 on setting up an IT enabled Financial Aid Authority which would look at scholarships and student loan together is a welcome step in this regard. However, this needs to be widened in order to examine holistically the relationship between the fees, grants and loans along with affordability. The arguments for distributive justice and targeting the provision at the deprived sections, is quite valid - in case of student loans-and equally public financing of higher education in India.

\section{Agenda for Future Research}

In this section, the paper raises more questions than it has answered on the issue of student loans and its relationship with fees, grants and family characteristics. The increasing trends in education loans raise a number of questions viz., What is the relationship between cost of higher education across courses and demand for student loans? Is demand for student loans is more as cost of higher education is increasing? How does it vary between public and private institutions of higher education? An attempt to answer these questions would require information at the institutional level on the cost of higher education (fee structure and other direct cost of higher education) by public and private institutions vis-avis enrolment in these institutions. Data on enrolment by public and private institutions is available from All India Higher Education Surveys. Information is barely available on cost of higher education in the public domain, except budgetary allocation towards higher education. At least on public universities, the budgets are available. With strenuous efforts, one can estimate the cost of higher education by courses at an institutional level. For instance, estimates on cost of courses in two public universities in Uttar Pradesh (Mathur, 2001) and cost structure across state universities in Karnataka (GOK, 2011) are few such examples. Many such institutional and state level studies are required for an informed and evidence based policy making in the Indian context. 
Second set of questions arise from the demand side include, who demands student loans? What is the relationship between family income, occupation and educational levels of parents and demand for student loans? An attempt to answer these questions require information such as individual and family's demographic and economic characteristics from prospective and current students enrolled in higher educational institutions. Few researchers collecting small samples attempted to understand this dynamics (Debi, 2010; Srinivasan and Das, 2011). How do banks respond to the demand for student loans is yet another dimension. It is important to note that banks have discretion as to who they loan to and how much and it is because banks require "..collateral security... in the form of suitable third party guarantee" (Table A1 in annexure 1). These issues can be examined if data is available from banks on those who applied for loans; among them who are sanctioned with loans, along with their household and economic characteristics, loan profile, etc.

However an ideal approach would be to examine cost of higher education, along with student support, student and family's income and expenditure. The relationship between family income and participation in higher education is extensively studied in order to determine the extent to which higher education has increasingly become the domain of students from well-to-do families in developed countries, but such studies rarely prevail for India. The relationship between fees, grants, loans and affordability in the Indian context needs to be examined so as to explicate where does the problem lie and strategies through which it can be addressed.

\section{Acknowledgment}

The author would like to thank the anonymous referee for the comments and suggestions which helped in improving the paper.

\section{Ethics}

There are no ethical issues that may arise on the publcation of this paper.

\section{References}

Agarwal, P., 2009. Indian Higher Education: Envisioning the Future. 1st Edn., Sage Publications, New Delhi, ISBN-10: 8178299410, pp: 520.

Asplund, R., O.B. Abdelkarim and A. Skalli, 2008. An equity perspective on access to, enrolment in and finance of tertiary education. Educ. Econom., 16: 261-274. DOI: 10.1080/09645290802338102
Avery, C. and S. Turner, 2012. Student loans: Do college students borrow too much-or not enough? J. Economic Perspectives, 26: 165-192. DOI: $10.1257 /$ jep.26.1.165

Barr, N. and I. Crawford, 2005. Financing Higher Education: Answers from the UK. 1st Edn., Routledge, New York, ISBN-10: 0415348579, pp: 314.

CABE, 2005. Report of the central advisory board of education committee on financing higher and technical education in India. Ministry of Human Resources and Development, New Delhi.

Calclough, C, G. Kingdon and H.A. Patrinos, 2009. The pattern of returns to education and its implications. Policy Brief, No. 4. Research Consortium on Educational Outcomes and Poverty.

Carneiro, P. and J.J. Heckman, 2002. The evidence on credit constraints in post-secondary schooling. Economic J., 1: 989-1018. DOI: $10.1111 / 1468-0297.00075$

Chapman, B., 2006. Government Managing Risk: Income Contingent Loans for Social and Economic Progress. 1st Edn., Routledge, ISBN-10: 1134444338, pp: 240.

Chattopadhyay, S., 2007. Exploring alternative sources of financing higher education. Economic Political Weekly, October 20, pp. 4251-59

Christie, H. and M. Munro, 2003. The logic of loans: Students' perceptions of the costs and benefits of the student loan. British J. Sociol. Educ., 24: 621-636. DOI: $10.1080 / 0142569032000127170$

Debi, S., 2010. Loan Financing to higher education: Experiences of bank financing in a less developed region. CMDR Monograph Series No. 56, Centre for Multi-disciplinary Development Research, Dharwad, Karnataka.

D'souza, E., 2004. Markets and Equity in Education. Economic Political Weekly, 39: 1107-1110.

Forsyth, A. and A. Furlong, 2003. Losing Out? Socioeconomic Disadvantage and Experience in Further and Higher Education. 1st Edn., The Policy Press, Bristol, ISBN-10: 1861345089, pp: 69.

Geetha Rani, P., 2013. Exploring earnings and education disparities across region, caste, religion and English language ability. Artha Vijnana, 55: 402-420.

Geetha Rani, P. 2014. Equity in the distribution of India's government subsidies on education. Int. J. Educ. Economic Dev., 5: 1-39. DOI: 10.1504/IJEED.2014.059862

Gicheva, D., 2012. In debt and alone? Examining the causal link between student loans and marriage. Working Paper. 
GOK, 2011. University finances: A Study of Karnataka State Universities. Karnataka Knowledge Commission, Department of Higher Education, Government of Karnataka, Bangalore.

Johnstone, D.B., 1986. Sharing the Costs of Higher Education: Student Financial Assistance in the United Kingdom, the Federal Republic of Germany, France, Sweden and the United States. 1st Edn., The College Board, New York, ISBN-10: 0874472784, pp: 184.

Maiti, D. and A. Mitra, 2010. Skills, informality and development. IEG working paper No. 306.

Mathur, S.P., 2001. Financial management in Indian Universities, Varanasi, Ganga Kaveri.

Mukherjee, A. and D. Satija, 2012. The consumption pattern of the rising middle class in India. Indian Council for Research on International Economic Relations, New Delhi, India.

NKC, 2006. National Knowledge Commission, Report to the Nation, Gouvernent of India, Planning Commission, New Delhi.

Shah, K.R., 2008. Traditional sources of financing higher education. Economic Political Weekly, 43: 74-76.

Shen, H. and A. Ziderman, 2009. Student loans repayment and recovery: International comparisons. Higher Educ., 57: 315-333.

DOI: $10.1007 / \mathrm{s} 10734-008-9146-0$
Srinivasan, R. and D. Das, 2011. Analysis of education loan: A case study of national capital territory of Delhi. Int. J. Manage. Strategy.

Talreja, C., 2014. India's demographic dividend: Realities and opportunities. Ind. J. Labour Econom., 57: 139-155.

Tilak, J.G., 2004. Public subsidies on education in India. Economic Political Weekly, 39: 343-359.

Usher, 2004. Are the poor needy? Are the Needy Poor? Distribution of Student Loans and Grants by Family Income Quartile in Canada, Education Policy Institute, Canada.

Usher, A., 2005. Global Debt Patterns: An International Comparison of Student Loan Burdens and Repayment Conditions. 1st Edn., Educational Policy Institute, Toronto.

Yashpal, 2009. Report of the committee to advise on renovation and rejuvenation of higher education. Ministry of Human Resource Development, New Delhi.

Woodhall, M., 2007. Funding Higher Education: The Contribution of Economic Thinking to Debate and Policy Development, Education Working Paper Series, No. 8, World Bank, Washington, D.C.

Ziderman, A., 2002. Financing student loans in Thailand: Revolving fund or open-ended commitment? Econom. Educ. Rev., 21: 367-380. DOI: $10.1016 / \mathrm{S} 0272-7757(01) 00024-3$

\section{Annexure 1}

Table A1. Education Loans by State Bank of India

\begin{tabular}{|c|c|}
\hline Criteria & Details \\
\hline Eligible Courses & $\begin{array}{l}\text { All courses having employment prospects; } \\
\text { Graduation/Post Graduate/Professional and Other courses approved by } \\
\text { UGC/Government/AICTE etc. }\end{array}$ \\
\hline Expenses covered for loan & $\begin{array}{l}\text { Tuition Fees; hostel and mess charges; Exam/Library/Laboratory fees; Purchase of Books etc; } \\
\text { Caution Deposit/Building Fund/Refundable Deposit (maximum } 10 \% \text { tuition fees for the entire } \\
\text { course); Travel abroad, Purchase of computers, etc, Cost of a Two-wheeler up to Rs. } 50,000 /-; \\
\text { Any other expenses required to complete the course like study tours, project work etc. }\end{array}$ \\
\hline Amount of Loan & $\begin{array}{l}\text { For studies in India, maximum Rs. } 1 \text { Million } \\
\text { Studies abroad, maximum Rs. } 2 \text { Million }\end{array}$ \\
\hline Interest Rates (with effect & For loans up to Rs. $4,00,000-0.50 \%$ below SBAR i.e., $12.25 \%$ p.a. Floating \\
\hline from 27th June 2008) & $\begin{array}{l}\text { For loans above Rs. } 4,00,000 \text { and up to Rs. } 7,50,000-1.00 \% \text { above SBAR } 13.75 \% \text { Floating } \\
\text { For loans above Rs. } 7,50,000 \text {-SBAR- } 12.75 \% \text { p.a. Floating }\end{array}$ \\
\hline Processing Fees & $\begin{array}{l}\text { No processing fee/ upfront charges } \\
\text { Deposit of Rs. 5000/- for education loan for studies abroad which will be adjusted in the margin } \\
\text { money }\end{array}$ \\
\hline Grace period & One year after completion of course or 6 months after securing a job, whichever is earlier \\
\hline Repayment Period & $\begin{array}{l}\text { Same } 5 \text { to } 7 \text { years for studies in India for Rs. } 1 \text { Million and for Studies in abroad for Rs. } 2 \\
\text { Million }\end{array}$ \\
\hline Collateral & $\begin{array}{l}\text { Up to Rs. } 4,00,000 \text {, there is no security required. From Rs. } 4,00,000 \text { to Rs. } 7,50,000 \text {, collateral } \\
\text { security is in the form of suitable third party guarantee; Above Rs.7,50,000, tangible collateral } \\
\text { is the security }\end{array}$ \\
\hline Margin & $\begin{array}{l}\text { No Margin for loans up to Rs. 4,00,000 For loans above Rs. 4,00,000-Studies in India: } 5 \% \\
\text { and Studies Abroad: } 15 \%\end{array}$ \\
\hline
\end{tabular}

Source: based on www.sbi.org downloaded as on 31.5.2010 
Table A2. Student Loans and Interest Subsidy by Income Quintiles by Caste in India (in Rs.)

\begin{tabular}{|c|c|c|c|c|c|c|}
\hline \multirow[b]{2}{*}{ Income Q } & \multicolumn{2}{|l|}{ General } & \multicolumn{2}{|l|}{ OBC } & \multicolumn{2}{|l|}{ SC\&ST } \\
\hline & Loan Sanctioned & Interest Subsidy & Loan Sanctioned & Interest Subsidy & Loan Sanctioned & Interest Subsidy \\
\hline & $2009-10$ & & & & & \\
\hline Q1 & 225961 & 4068 & 190481 & 3540 & 172388 & 3206 \\
\hline Q2 & 216338 & 4060 & 189711 & 3912 & 176374 & 3470 \\
\hline Q3 & 234923 & 4622 & 207084 & 4284 & 197691 & 3930 \\
\hline Q4 & 265531 & 5683 & 230855 & 4853 & 216399 & 4328 \\
\hline Q5 & 305110 & 6445 & 258048 & 5264 & 258019 & 4921 \\
\hline Total & 253839 & 5105 & 209570 & 4243 & 203284 & 3944 \\
\hline Inc. Gap ${ }^{\wedge}$ & 1.35 & 1.58 & 1.35 & 1.49 & 1.50 & 1.53 \\
\hline Inc-Caste* & -- & -- & 1.60 & 1.82 & 1.77 & 2.01 \\
\hline Income Q & $2010-11$ & & & & & \\
\hline Q1 & 210672 & 6990 & 174537 & 5874 & 152039 & 5231 \\
\hline Q2 & 218096 & 7515 & 184441 & 6354 & 167945 & 5888 \\
\hline Q3 & 241013 & 8668 & 207517 & 7352 & 192667 & 7018 \\
\hline Q4 & 267608 & 9907 & 225380 & 7896 & 212150 & 7449 \\
\hline Q5 & 306761 & 11406 & 257820 & 9273 & 256344 & 8971 \\
\hline Total & 253506 & 9111 & 202344 & 7045 & 191877 & 6735 \\
\hline Inc. Gap^ & 1.46 & 1.63 & 1.48 & 1.58 & 1.69 & 1.72 \\
\hline Inc-Caste* & -- & -- & 1.76 & 1.94 & 2.02 & 2.18 \\
\hline Income Q & $2011-12$ & & & & & \\
\hline Q1 & 216864 & 10679 & 177661 & 7830 & 154329 & 6673 \\
\hline Q2 & 223197 & 11380 & 184413 & 8843 & 164975 & 7211 \\
\hline Q3 & 246952 & 13063 & 208596 & 10118 & 191009 & 9203 \\
\hline Q4 & 275504 & 15146 & 233169 & 11696 & 214682 & 10698 \\
\hline Q5 & 313474 & 17886 & 262217 & 12818 & 256223 & 12552 \\
\hline Total & 259388 & 13939 & 205453 & 9820 & 191370 & 8935 \\
\hline Inc. Gap ${ }^{\wedge}$ & 1.45 & 1.67 & 1.48 & 1.64 & 1.66 & 1.88 \\
\hline Inc-Caste* & -- & -- & 1.76 & 2.28 & 2.03 & 2.68 \\
\hline Income Q & $2012-13$ & & & & & \\
\hline Q1 & 221452 & 14363 & 184320 & 11277 & 162957 & 9698 \\
\hline Q2 & 225251 & 14118 & 183470 & 10644 & 169963 & 9604 \\
\hline Q3 & 244695 & 15677 & 202702 & 11883 & 188347 & 10838 \\
\hline Q4 & 278483 & 18975 & 238163 & 14893 & 212075 & 13126 \\
\hline Q5 & 314524 & 20917 & 267115 & 16580 & 258335 & 15919 \\
\hline Total & 262237 & 17256 & 208544 & 12629 & 193230 & 11534 \\
\hline Inc. Gap ${ }^{\wedge}$ & 1.42 & 1.46 & 1.45 & 1.47 & 1.59 & 1.64 \\
\hline Inc-Caste* & -- & -- & 1.71 & 1.85 & 1.93 & 2.16 \\
\hline
\end{tabular}

Note: Income Q indicates income quintile. We divide the borrowers into five quintiles using parental income and compare few key determinants' summary statistics on them; ^ Income Gap; * Income-Caste Gap; Source: Unit data

\section{Annexure 2}

\section{Central Sector Interest Subsidy Scheme on} Education Loans

Department of Higher Education, Ministry of Human Resource Development, Government of India has launched this interest subsidy scheme with the main purpose of helping the economically weaker sections. The supplementary objectives of the scheme are to promote equity, public accountability and innovation. The scheme is available to those students who belong to economically weaker sections and aspire to access higher education with parental income of less than Rs 4.5 lakh per annum. The details of the interest subsidy scheme include the following:
- Interest payable for professional courses for the period of moratorium (i.e., course period, plus one year or six months after getting job, whichever is earlier) is borne by the central government. Interest on outstanding loan amount to be paid by student;

- Interest subsidy is available to the eligible students only once, either for the first undergraduate degree course or the post graduate degrees/diplomas. However, interest subsidy is admissible for combined undergraduate and post graduate courses

- Interest subsidy is not available for those students who either discontinue, or for those who are expelled from the Institutions on disciplinary or academic grounds but available for discontinuation due to medical grounds 
- As on offshoot of this interest subsidy scheme, those students who availed this interest subsidy will get $1 \%$ concession in interest rates as per the design of the Indian Bank Association (IBA) scheme on student loans. The details of the educational loan and interest subsidy schemes have been hosted in the website of Ministry of Human Resource Development as well as IBA 